\title{
Kışlık Buğdayda Farklı Toprak İşleme Tekniklerinin Toprak Nem İçeriği ve Verim Parametreleri Üzerine Etkisi*
}

\author{
Feride ÇAPAR, Kenan UÇAN** \\ KSÜ, Ziraat Fakültesi, Biyosistem Mühendisliği Bölümü, Kahramanmaraş
}

Geliş (Received): 05.02.2015

Kabul (Accepted): 11.05.2015

\begin{abstract}
ÖZET: Bu çalışma, doğrudan ekim (DE), az işlenmiş ekim (AİE) ve geleneksel ekim (GE) tekniklerinin toprak nem içeriği ve ürün verimine etkilerinin araştırılması amacı ile bir tarla çalışması olarak yapılmıştır. Araştırma, 2014 yılında Kahramanmaraş Sütçü İmam Üniversitesi Avşar Yerleşkesi içerisindeki tarım alanında kışlık buğday bitkisi yetişme sezonu boyunca yürütülmüştür. Araştırma tesadüf blokları deneme deseninde üç tekerrürlü olarak kurulmuştur. Araştırmada kışlık buğday için sulamasız koşullarda su tüketimi $321.0 \mathrm{~mm}$ olurken, sulama zamanı planlamasına göre bitkinin ihtiyaç duyduğu toplam net sulama suyu miktarı $501.2 \mathrm{~mm}$ olmuştur. Toprağın $0-30$ cm'lik kısmında yetişme periyodunun ilk zamanlarında ekim teknikleri arasında nem içeriği yüksek çıkmıştır. Hasata doğru bu fark azalmış ve sırasıyla toprak nem içerikleri DE'de \%15.6, AİE'de 15.4 ve GE'de 15.3 olarak bulunmuştur. Toprak derinliğinin 30-60 ve 60-90 cm'sinde nem düzeyleri büyükten küçüğe doğru DE, AİE ve GE teknikleri şeklinde bir sıralama göstermişlerdir. Fakat bu değerler $0-30 \mathrm{~cm}$ toprak katmanına göre daha yakın çıkmıştır. Hasatta 30-60 cm toprak katmanında nem değerleri DE'de \%15.9, AİE'de 15.9 ve GE'de 15.6 iken 60-90 cm toprak katmanında ise nem değerleri DE'de \%16.4, AİE'de 16.2 ve GE'de 16.1 olarak bulunmuştur. Hasatta 0$30 \mathrm{~cm}$ katmana göre 30-60 ve 60-90 katmanındaki nem değerleri daha yüksek çıkmıştır. İncelenen parametrelerden; başak boyu üzerinde toprak işleme tekniklerinin etkisi \% 5 olasılık düzeyinde istatistiksel olarak önemli bulunmuştur. DE, AİE ve GE' de sırasıyla en uzun başak boyu 7.9, 7.8 ve $7.4 \mathrm{~cm}$ olarak ölçülmüştür. Bitki boyu, bin tane ağırlı̆̆ı, başaktaki başakçık sayısı, başaktaki tane sayısı, tane verimi, sap verimi, toplam verim, hasat indeksi ve tane nemi bakımından varyans analizinde toprak işleme teknikleri arasında istatistiksel olarak önemli farklılıklar olmasa da DE tekniğinde sonuçlar daha yüksek çıkmıștır.
\end{abstract}

Anahtar Kelimeler: Ekim Teknikleri, Kışlık Buğday, Toprak İşleme

\section{Effect on the Soil Moisture Content and Yield Parameters of Different Tillage Techniques in the Winter Wheat}

ABSTRACT: This study was conducted as a field study to determine the effect of soil moisture content and yield of reduced tillage (RT), direct (D) and traditional (T) the cultivation techniques. The study was conducted in the research area in the Avsar Campus of the Kahramanmaras Sutcu Imam University throughout the growing season of winter wheat plants in 2014. The study was conducted on a three replication on randomized complete block design. The study was water consumption in without irrigation conditions for winter wheat in the research $321.0 \mathrm{~mm}$, whereas according the irrigation time planning the amount of irrigation water of plant $501.2 \mathrm{~mm}$. Moisture content were found higher between planting techniques in the first time period of growth in the 0-30 cm layer of the soil. This difference decreased to the harvest and also D, RT and T respectively, $15.6 \%, 15.4 \%$ and $15.3 \%$. D, RT and T techniques demonstrated in the form of a ranking from small to large the soil humidity levels 30-60 and 60-90 cm of soil depth. However, this value was closer than the $0-30 \mathrm{~cm}$ soil layer. In the harvest were the moisture values in 30 $60 \mathrm{~cm}$ soil layer in D, RT and T respectively, $15.9 \%, 15.9 \%$ and $15.6 \%$, also in the 60-90 cm soil layer moisture values D, RT and T respectively, $16.40 \%, 16: 2 \%$ and 16:1\%. The harvest humidity was higher $30-60 \mathrm{~cm}$ and $60-90$ $\mathrm{cm}$ according to 0-30 $\mathrm{cm}$ layer. The effect of tillage techniques on spike length was found $5 \%$ probability level to be statistically significant. It were measured the longest spike length in the D, RT and T, respectively, 7.9, 7.8 and 7.4 $\mathrm{cm}$. Plant height, thousand grain weight, spikelet number per spike, number of grains per spike, total yield, straw yield, harvest index and grain moisture were non-significant differences statistically between tillage techniques in the variation analyzed but the results of $\mathrm{D}$ technique was higher.

Keywords: Sowing Techniques, Winter Wheat, Tillage

\section{GíRIŞ}

Son zamanlarda tüm dünyada artmaya başlayan kuraklıklar, suyun daha etkili bir şekilde kullanılması gerekliliğini ortaya koymaktadır. Dünyada olduğu gibi ülkemizde de su, en fazla tarım sektöründe (\%73) kullanılmaktadır (Anonim, 2015). En fazla su kayıplarının tarımda olması nedeniyle en fazla su tasarrufu da sulamada yapılmalıdır. Sulamadan beklenen yararı sağlayabilmek için temel koşul, bitkinin ihtiyaç duyduğu miktardaki suyun yağışlarla karşılanamayan bölümünün toprakta bitkinin kök bölgesine gereken zamanda ve gereken miktarda verilmesidir (Biber ve Kara, 2006). Toprak neminin korunması ve bitki kök bölgesinde suyun daha uzun

*Birinci yazarın yüksek lisans tezinden özetlenmiştir.

**Sorumlu yazar: Uçan, K., ucan@ksu.edu.tr 
süre tutulmasını sağlayan uygulamalar sulamayı daha etkin kılmaktadır. Bu uygulamalardan biri floküle edici veya yapıştırıcı özelliği olan bazı organik ve inorganik materyallerin toprağa karıştırılmasıdır. Özellikle agregat stabilitesi ve su tutma kapasitesi düşük olan kumlu topraklara, çeşitli formlarda organik madde ve inorganik toprak düzenleyici ilave edilmesi toprağın su tutma kapasitesini arttırmaktadır (Brady ve Weil, 1996). Bu amaçla kullanılabilecek birçok organik ve inorganik materyal vardır. Fakat kullanılan bu materyaller ekonomik ve ekolojik dengeyi bozmayacak nitelikte olmalıdır (İşler, 2012). Buna bağlı olaraktan insanlar yeni arayışlar içine girmiştir. Bunlardan biriside farklı toprak işleme teknikleri ile toprak nemini koruma yoludur.

Korumalı tarım, genel bir kavram olup, toprak işlemesiz tarım, en az toprak işleme, sırta ekim, anıza doğrudan ekim gibi terimlerin tümünü içinde barındırmaktadır. Toprak işleme, toprağın gözenek karakterlerini etkileyerek infiltrasyon ve su tutma kapasitesinin değişimine neden olmaktadır. Topraktaki makro gözenek miktarındaki artış, toprağın su tutma kapasitesi azaltırken, mikro gözeneklerin artışı ise toprağın su tutma kapasitesini artırmaktadır. Bitkisel üretimde verimi artıran en önemli etmenlerden biri farklı toprak işleme sistemlerinden uygun olanı seçmektir. Bununla birlikte; toprak işleme yoğunluğunun artışına paralel olarak tarla trafiği ve toprak sıkışması artmakta ve bunun sonucunda da infiltrasyon oranında azalma meydana gelmektedir.

Ülkemizin çoğunluğu yarı-kurak, bazı bölgeleri ise yarı-nemli iklime sahiptir. Her iki iklim bölgesinde de üretim sezonu boyunca düşen yağışların yetersiz ve düzensiz olması nedeniyle bitki yetiştiriciliğinde, sulama yapılmasına, sulama imkânının olmadığı yerlerde ise topraktaki nemin korunmasının gereksinimi duyulmaktadır. Ülkemizde buğday tarımı, büyük ölçüde kuru koşullarda yapıldığ 1 için verim düşük ve dolayısıyla buğday üreticisinin geliri de diğer ürün yetiştiricilerine göre daha az olmaktadır. Ayrıca bazı tarım bölgelerimizde yaşanan iklim özelliklerinden dolayı buğdaydan başka bir üründe karlı bir yetiştiricilik yapmak mümkün değildir. $\mathrm{Bu}$ nedenle; bu tarım alanlarımızda, buğdayla aynı yetişme sezonunda rekabete girecek ve marjinal kazancı yüksek başka bir ürün bulunmamaktadır.

Ülkemizde farklı toprak işleme uygulamalarının toprak nem içeriği üzerindeki etkisini belirlemeye yönelik yapılmış çalışma sayısı oldukça azdır. Kahramanmaraş'ta buğday+buğday münavebesinde genellikle geleneksel toprak işleme tekniği ile ekim yapılmaktadır. $\mathrm{Bu}$ çalışmada, koruyucu toprak işleme tekniğinin toprakta nem içeriği değişimine etkisi gözlemlenmiş ve bunun için doğrudan ekim (DE), az işlenmiş ekim (AİE) ve geleneksel ekim (GE) teknikleri karşılaştırılmıştır. Ayrıca sulamasız koşullarda anılan tekniklerin verim ve verim parametreleri üzerine etkileri de araştırılmıştır.

\section{MATERYAL ve METOT}

Araştırma, 2014 yılında Kahramanmaraş Sütçü İmam Üniversitesi Avşar Yerleşkesi içerisindeki arazide yürütülmüştür. Araştırmanın yapıldığı yerin denizden ortalama yüksekliği $512 \mathrm{~m}$ olup $37^{\circ} 35^{\prime} \mathrm{N}$ enlemi ve $36^{\circ} 48^{\prime}$ E boylamında yer almaktadır (Şekil 1). Arazi hafif eğimli olup drenaj yetersizliği bulunmamaktadır.

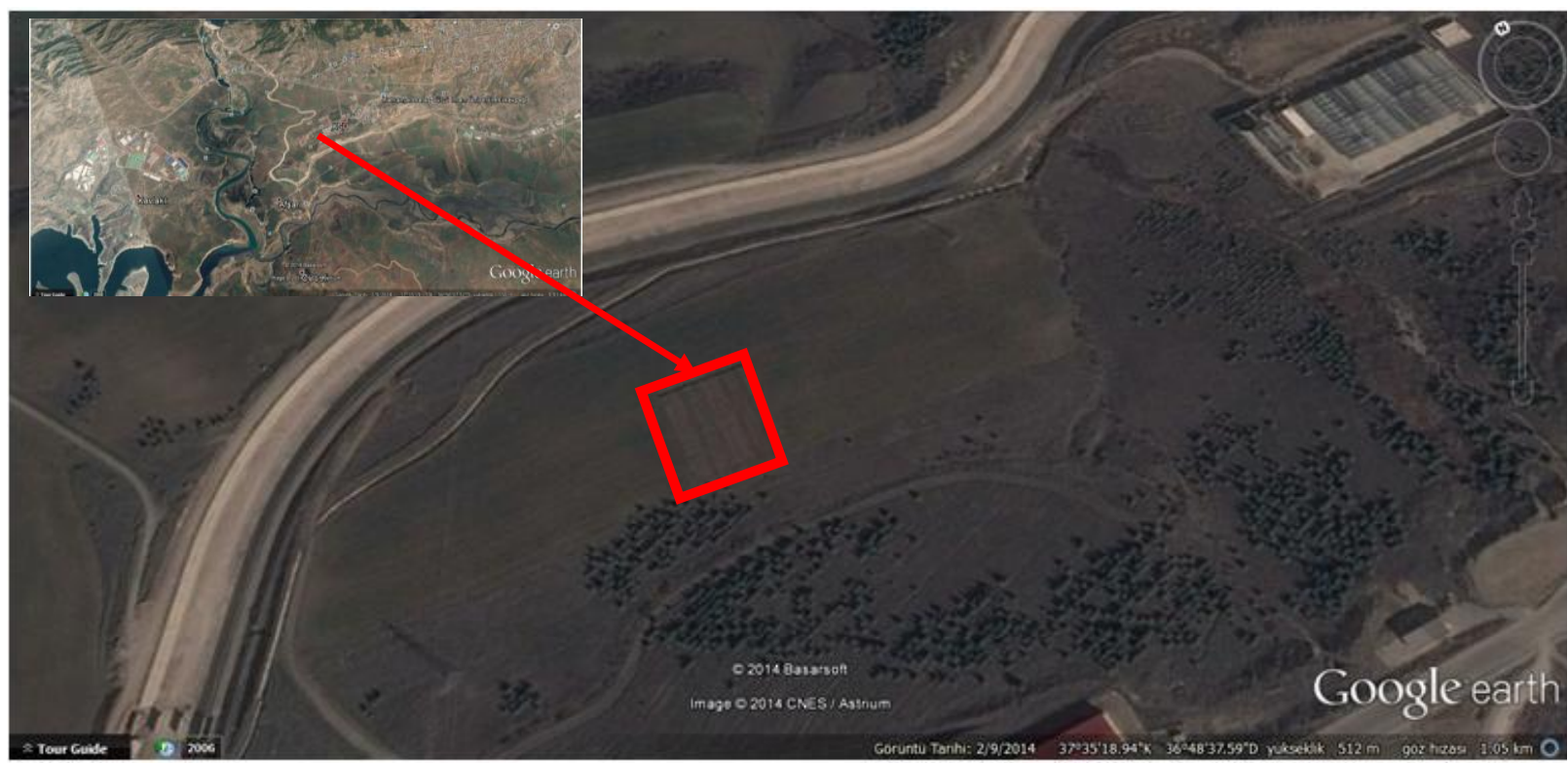

Şekil 1. Çalışma alanının Google Earth görüntüsü

Araştırmanın yürütüldüğü bölgede kışları soğuk ve yağışl1, yazları kurak ve sıcak olan tipik Akdeniz ikliminin özellikleri görülmektedir. Araştırmanın yapıldığı alanda buğdayın 2014 yılı yetişme dönemine ait iklim verileri deneme alanına konumlandırılmış iklim istasyonu ile ölçülmüştür. Araştırma alanında 
buğday yetiștirme dönemine ait ölçülen yıllık ve uzun yıllık iklim verileri Çizelge 1'de verilmiştir (Anonim.

2014).

Çizelge 1. Araştırma alanında buğday yetiştirme dönemine ait yıllık ve uzun yıllık iklim verileri

\begin{tabular}{|c|c|c|c|c|c|c|c|c|}
\hline Yil & İklim Parametreleri & Aralık* & Ocak & Şubat & Mart & Nisan & Mayıs & Haziran \\
\hline \multirow{6}{*}{$\underset{\sim}{\stackrel{\Xi}{~}}$} & Max.Sicaklık $\left({ }^{\circ} \mathrm{C}\right)$ & 10.9 & 12.8 & 15.8 & 18.7 & 24.0 & 28.0 & 32.6 \\
\hline & Min. Sicaklık $\left({ }^{\circ} \mathrm{C}\right)$ & 3.0 & 4.5 & 4.0 & 8.5 & 12.0 & 15.3 & 19.6 \\
\hline & Ort. Sicaklık $\left({ }^{\circ} \mathrm{C}\right)$ & 5.6 & 9.8 & 8.8 & 12.8 & 16.4 & 20.8 & 21.4 \\
\hline & Yağış (mm) & 48.7 & 76.5 & 27.0 & 112.4 & 30.2 & 10.3 & 6.0 \\
\hline & Oransal Nem (\%) & 78.0 & 73.9 & 54.2 & 56.3 & 58.9 & 50.2 & 51.9 \\
\hline & Rüzgar Hızı (m/s) & 1.30 & 0.85 & 0.52 & 1.18 & 0.81 & 1.35 & 1.15 \\
\hline \multirow{6}{*}{ 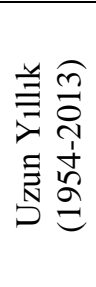 } & Max.Sicaklik $\left({ }^{\circ} \mathrm{C}\right)$ & 11.1 & 9.2 & 10.8 & 15.7 & 21.1 & 26.7 & 31.9 \\
\hline & Min. Sicaklık $\left({ }^{\circ} \mathrm{C}\right)$ & 3.1 & 1.2 & 2.2 & 5.6 & 9.8 & 14.1 & 18.8 \\
\hline & Ort. Sicaklık $\left({ }^{\circ} \mathrm{C}\right)$ & 6.6 & 4.8 & 6.3 & 10.6 & 15.4 & 20.3 & 25.2 \\
\hline & Yağış (mm) & 128.9 & 129.6 & 114.3 & 96.2 & 75.5 & 41.0 & 6.6 \\
\hline & Oransal Nem (\%) & 69.7 & 71.1 & 73.2 & 52.5 & 51.9 & 51.0 & 41.5 \\
\hline & Rüzgar Hızı (m/s) & 0.7 & 0.9 & 1.1 & 1.4 & 1.7 & 1.9 & 2.9 \\
\hline
\end{tabular}

*Aralık ayına ait yıllık değerler 2013 yılına ait değerlerdir.

Bitkinin yetişme döneminin en yağışlı geçen ayı Mart olurken en kurak geçen ayı Haziran olmuştur. Uzun yıllık aylık yağış değerlerine göre Mart ayı hariç diğer bütün aylar nispeten kurak geçmiştir. Bu dönemde toplam yağış miktarı $311.1 \mathrm{~mm}$ olmuştur. Alanda yıllık toplam yağışın \%40-45'i kış aylarında düşmektedir. Yağışın büyük bir bölümü yağmur şeklindedir.
Deneme alanının farklı noktalarından alınan bozulmuş ve bozulmamış toprak örneklerinin analizi sonucunda toprağın bazı fiziksel ve kimyasal özellikleri Çizelge 2'de verilmiştir.

Çizelgede görüldüğü gibi deneme alanı topraklarının profil boyunca katmanların killi-tınlı ve killi olduğu saptanmıştır. Ayrıca $90 \mathrm{~cm}$ profil derinliğindeki kullanılabilir su miktarı $136.0 \mathrm{~mm}$ olarak belirlenmiştir.

Çizelge 2. Araștırma alanı topraklarının bazı fiziksel ve kimyasal özellikleri

\begin{tabular}{|c|c|c|c|c|c|c|c|}
\hline $\begin{array}{c}\text { Toprak } \\
\text { Derinliği } \\
(\mathrm{cm})\end{array}$ & $\begin{array}{c}\mathrm{TK} \\
(\mathrm{Pv}, \%)\end{array}$ & $\begin{array}{c}\mathrm{SN} \\
(\mathrm{Pv}, \%)\end{array}$ & $\begin{array}{c}\text { Hacim Ăg. } \\
\left(\mathrm{g} / \mathrm{cm}^{3}\right)\end{array}$ & $\mathrm{pH}$ & $\begin{array}{c}\mathrm{EC} \\
(\mathrm{dS} / \mathrm{m})\end{array}$ & $\begin{array}{c}\mathrm{CaCO}_{3} \\
(\%)\end{array}$ & Bünye \\
\hline $0-30$ & 28.8 & 11.5 & 1.4 & 6.9 & 0.02 & 1.6 & CL (killi tınlı) \\
\hline $30-60$ & 28.4 & 12.9 & 1.4 & 7.1 & 0.01 & 2.3 & CL (killi tınlı) \\
\hline $60-90$ & 25.2 & 12.5 & 1.3 & 7.2 & 0.02 & 2.2 & C (killi) \\
\hline
\end{tabular}

Pv: Hacim yüzdesi cinsinden nem miktarı, TK: Tarla kapasitesi, SN: Solma noktası, EC: Elektriksel iletkenlik

Yürütülen bu denemede buğday çeşidi olarak bölgede yaygın olarak yetiştirilen Ceyhan-99 çeşidi kullanılmıştır. Ceyhan-99 çeşidi; kışa ve kurağa orta derecede dayanıklı ekmeklik bir buğday çeşididir.

Çalışmada koruyucu toprak işleme sisteminde değinilen geleneksel toprak işleme tekniği (GE) doğrudan ekim tekniği (DE) ve az işlenmiş ekim tekniği (AİE) karşılaştırılmıştır. Yöntemlere ilişkin detaylar ve yapılan kültürel işlemler Çizelge 3'de verilmiştir. Çalışma tesadüf blokları deneme deseninde üç tekerrürlü olarak yürütülmüştür. Deneme parselleri $4 \mathrm{x}$ $50=200 \mathrm{~m}^{2}$ şekilde $12 \mathrm{~cm}$ sıra aralığında deneme

Bitki kök bölgesinin belirli derinliklerdeki nem içeriğinin takibinde toprak nem ölçer (TDR, Time Domain Reflectometry-Zaman Etkili Yansıma Ölçer) aleti kullanılmıştır. Deneme alanında toprağın nem içeriğini belirlemek üzere her parselde 3 ayrı noktadan mibzeri ile ekilmiştir. Ekim işlemi sonrasındaki bakım işleri bütün parsellerde aynı yapılmıştır.

Çizelge 3. Toprak ișleme teknikleri

\begin{tabular}{|c|l|}
\hline $\begin{array}{c}\text { Ekim } \\
\text { Teknikleri }\end{array}$ & \multicolumn{1}{|c|}{ Kullanılan Ekipmanlar } \\
\hline DE & Doğrudan tahıl ekim makinesi \\
\hline AİE & $\begin{array}{l}\text { Rototiller ve merdanenin kombine alet } \\
\text { olarak kullanımı }\end{array}$ \\
\hline GE & $\begin{array}{l}\text { Pulluk, Yaylı kültivatör + Diskli tırmık } \\
(2 \mathrm{kez})+\text { Tapan + Tahıl ekim makinesi }\end{array}$ \\
\hline
\end{tabular}

ve her bir noktanın 0-30 cm, 30-60 cm, 60-90 cm derinliklerinden TDR probları Şubat ayında toprağa gömülerek haftada iki defa ölçümler alınmıştır, Aletin kalibrasyonu gravimetrik yöntem ile yapılmıştır. 
Konuların sulamasız koșullardaki su tüketimlerinin hesaplanmasında bütçe eşitliğine dayanan nem azalma yöntemi kullanılmıştır (James, 1988). Bu amaçla 1 nolu eşitlikten yararlanılmıştır.

$\mathrm{ET}=\mathrm{P}-\mathrm{Rf}-\mathrm{Cr}-\mathrm{Dp} \pm \Delta \mathrm{S}$

Eşitlikte; ET: Bitki su tüketimi $(\mathrm{mm}), \mathrm{P}$ : Yağış $(\mathrm{mm})$, Rf: Yüzey akış kayıpları $(\mathrm{mm})$, Cr: Kılcal yükseliş $(\mathrm{mm}), \mathrm{Dp}$ : Derine sızma miktarı $(\mathrm{mm})$ ve $\Delta \mathrm{S}$ : Kök bölgesinde toprak su içeriğindeki değişimdir (mm).

Deneme süresince düşen yağış miktarları ve bazı iklim parametreleri, deneme alanına yerleştirilen iklim istasyonu ile belirlenmiștir. Yapılan nem gözlemlerinde topraktaki nem tarla kapasitesinin üzerine çıkmadığı için yüzey akış ve derine sızma olmamıştır.

Araştırma alanında yetiştirilen bitkilerin gerçek su tüketimleri FAO tarafından geliştirilen PenmanMonteith yöntemine göre hesaplama yapan CROPWAT (8.0) paket programı yardımıyla hesaplanmıştır (Smith, 1991).

Referans bitki su tüketimi elde edildikten sonra, alanda tarımı yapılan bitkilerin $\mathrm{k}_{\mathrm{c}}$ bitki katsayısı değerleri İlbeyi, (2001) tarafindan yapilan doktora tez çalışmasından elde edilmiştir. $\mathrm{Bu}$ çalışmada farklı bölgeler için verilen $\mathrm{k}_{\mathrm{c}}$ katsayılarından bölge şartlarına uygun (geçiş bölgeleri) olan $\mathrm{k}_{\mathrm{c}}$ katsayısı aşağıdaki verilen Eşitlik 2'de göre referans bitki su tüketimi ile çarpılarak bitki su tüketimi değeri bulunmuşstur.

(2)

$\begin{array}{llll}\text { ET } & = & k_{c} & \text { ET }_{0}\end{array}$

Eşitlikte; ET: Bitki su tüketimi, (mm/gün), $\mathrm{k}_{\mathrm{c}}$ : Bitki katsayıs1 ve $\mathrm{ET}_{\mathrm{o}}$ : Referans bitki su tüketimidir (mm/gün).

Hesaplanan bitki su tüketiminin yağışlarla karşılanan miktarının belirlenmesi amacıyla yöre için verilen aylık ortalama yağı̧ miktarları dikkate alınarak etkili yağış miktarları USDA-SCS yöntemine göre hesaplanmıştır (Ünlükalayc1, 1994; Beyribey, 1992).

Su kullanma randımanı aşağıda verilen Eşitlik 3 ile belirlenmiştir (Howell vd., 1990).

$$
W U E=\frac{Y}{E T}
$$

Eşitlikte; WUE: Su kullanım randımanı (kg/ha mm), Y: Konulardan elde edilen buğday dane verimi $(\mathrm{kg} / \mathrm{ha})$ ve ET: Evapotranspirasyondur (mm).

Araştırmada verim ve verim unsurları ile ilgili olarak yapılan ölçüm ve tartımlar; her parselin kenarlarından ikişer sıra ve parsel başlarından 1'er m'si kenar tesiri olarak atıldıktan sonra kalan parsel alanında tesadüfen seçilen 10 bitkinin ana sapları etiketlenerek, bu bitkiler üzerinde yapılmıştır. Hasat olgunluğuna gelen parsellerde hasat işlemi yapılmıştır. Çalışmada her parsel için Kırtok (1982), Dinçer (1991), Akkaya ve Akten (1988), Uluöz (1965), uygulamış oldukları yöntemler esas alınarak; bitki boyu, başak boyu, başaktaki başakçık sayısı, başaktaki tane sayısı, bin tane ağırlı̆̆ı, tane verimi, sap verimi, toplam verim, hasat indeksi ve tane nemi değerleri hesaplanmıştır.

Elde edilen sonuçlar varyans analizine tabi tutularak farklar Duncan çoklu karşılaştırma yöntemine göre test edilmiștir. İstatistiki analizlerde SPSS Statistics 17.0 paket programından yararlanılmıştır.

\section{BULGULAR ve TARTIŞMA}

Kültürrel İșlemler ve Fenolojik Gözlemler

Çalışmada 2013 ve 2014 yıllarında tohum ekiminden hasada kadar geçen dönemde yapılan kültürel işlemler ve fenolojik gözlemler Çizelge 4'de verilmiştir. Bitkinin yetişme süresi 191 gün olarak gerçekleşmiştir.

Çizelge 4. Kültürel işlemler ve fenolojik gözlemler

\begin{tabular}{|l|c|}
\hline \multicolumn{1}{|c|}{ Fenolojik Gözlemler } & Tarihler \\
\hline Parsellerin oluşturulması & 25.11 .2013 \\
\hline Toprak işleme ve ekim & 02.12 .2013 \\
\hline Çimlenme & 13.12 .2014 \\
\hline Kardeşlenme & 21.03 .2014 \\
\hline İlaçlama & 23.03 .2014 \\
\hline Sapa kalkma & 25.03 .2014 \\
\hline Başaklanma & 14.04 .2014 \\
\hline Çiçeklenme & 22.04 .2014 \\
\hline Süt olumu & 05.05 .2014 \\
\hline Hasat & 11.06 .2014 \\
\hline
\end{tabular}

\section{Toprak Nem İçeriği}

Farklı toprak işleme tekniklerinin toprak nem içeriği üzerindeki etkisinin belirlemek amacıyla ekimden 77 gün sonra 18.02.2014 tarihinde TDR ölçümlerine başlanmıştır. $\mathrm{Bu}$ amaçla toprağın $15-45-75 \mathrm{~cm}$ derinliklere yerleştirilmiş TDR propları kullanılmışıır. Aletin kalibrasyonu gravimetrik yönteme göre yapılmış ve elde edilen kalibrasyon grafiğgi Şekil 3'de verilmiştir. TDR kalibrasyon eğrisi kullanılarak okunan Ka sayım değerleri nem değerlerine dönüştürülmüştür. Çalışmada TDR ölçümlerine ait toprak nemi değerleri farklı toprak derinliklerine bağlı olarak $(0-30 \mathrm{~cm}, 30-60 \mathrm{~cm}, 60-90$ $\mathrm{cm})$ Şekil 4'de verilmiştir. 


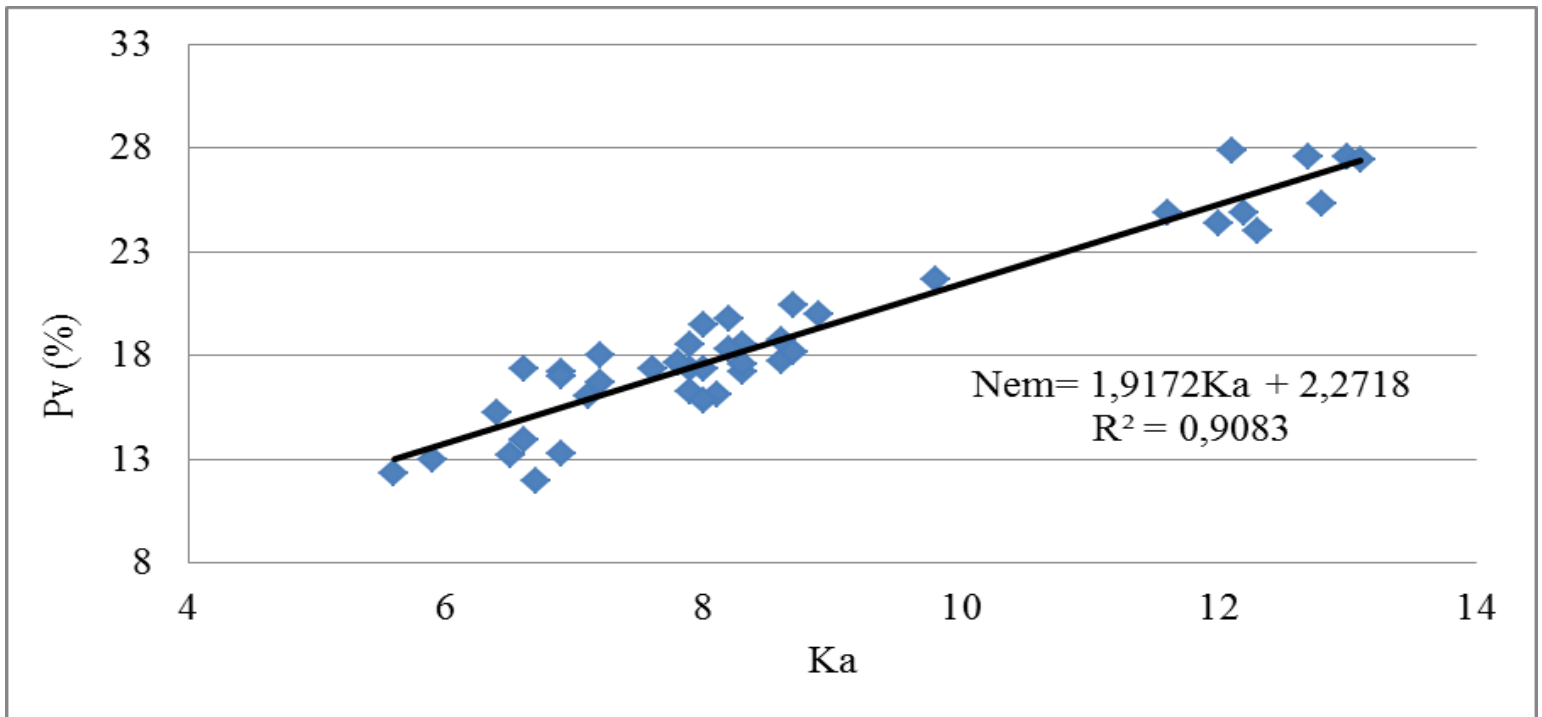

Şekil 3. TDR kalibrasyon eğrisi

Şekil 4'de 0-30 cm derinlikte konular arasında yetişme periyodu boyunca farklı nem değerleri elde edilmiştir. Yağışlara bağlı olarak grafikte yükselme ve alçalmalar olsa da toprakta nemin en iyi korunduğu ekim yöntemi DE tekniği olurken, AİE ve GE tekniğinde bu durum tam olarak gözlenememiştir. 0-30 $\mathrm{cm}$ toprak katmanında yetişme periyodunun ilk zamanlarında farklı ekim teknikleri arasında nem içeriği yüksek çıkarken hasata doğru bu fark azalmış ve sirasiyla DE'de \%15.6, AİE'de 15.4 ve GE'de 15.3 olarak bulunmuştur. Farklı ekim yöntemlerinin uygulandığ 1 parsellerin $30-60$ ve $60-90 \mathrm{~cm}$ 'sinde nem düzeyleri büyükten küçüğe doğru $\mathrm{DE}$, AİE ve GE teknikleri şeklinde bir sıralama göstermişlerdir. Fakat bu değerler 0-30 cm toprak katmanına göre daha yakın çıkmıștır. Hasatta 30-60 cm toprak katmanında nem değerleri DE'de \%15.9, AİE'de 15.9 ve GE'de 15.6 iken $60-90 \mathrm{~cm}$ toprak katmanında ise nem değerleri DE'de \%16.4, AİE'de 16.2 ve GE'de 16.1 olarak bulunmuştur. Hasatta 0-30 cm katmana göre 30-60 ve 60-90 katmanındaki nem değerleri daha yüksek çıkmıştır. Her üç katmanda vejetasyon devresi boyunca topraktaki nem seviyesi $0-30, \quad 30-60$ ve 60-90 katmanlarda sırasıyla kullanılabilir nemin \%50'sinin tüketildiği kritik nem seviyeleri olan \%20.1, \%20.7 ve $\% 18.8$ olan nem düzeylerinin altında kalmıştır. Hoogmoed ve Rawitz (1979), Hollanda'da yürüttükleri bir araştırmada, kuru tarımda buğday ve fiğ veriminin mutlak suretle toprak nemine bağlı olduğu, toprak işlemesinin azalması ile toprağın fiziksel ve kimyasal şartlarının iyileştiği ve bununda verimde artış sağladığını ortaya koymuşlardır. Toprak su içeriğini ise, sıfır toprak işlemede geleneksel işlemeye göre ilk ay yüksek, takip eden aylarda ise daha düşük bulmuşlardır. İnfiltrasyon sıfır toprak işlemede daha fazla olmasına rağmen, bu sistemde su kullanımı ve verimin daha iyi olduğunu bildirmişlerdir.

Kışlık buğday daha çok sulama imkânı olmayan kurak tarım arazilerinde yetiştirilmektedir. Bunun nedeni kış ve erken ilkbahar yağışlarından maksimum seviyede faydalanmaktır. Kurak geçen yıllarda yağış miktarı ve bunun vejetasyon dönemindeki dağılımı (yağış rejimi) yıldan yıla büyük değişiklikler göstermektedir. Özellikle kış ve ilkbaharda görülen mevsim kuraklıkları buğday üretiminde büyük sapmalara neden olmaktadır. DE tekniği tarla trafiğini en aza indirerek toprak sıkışmasını ortadan kaldırması, toprağın infiltrasyon hızını artırması gibi olumlu etkilerinden dolayı yağışın depolanmasına hız kazandırır. $\mathrm{Bu}$ durum yıl içinde görülen kuraklıkların olumsuz etkisinin azalmasına neden olur. GE tekniğinde ise, tarla trafiğinin fazla olması toprak sıkışması, toprağın infiltrasyon hızını azalması gibi olumsuz etkilerinden dolayı yağışın depolanmasını azaltır. Ayrıca GE'de nemli toprak katmanının yukarı çıarılması buharlaşmanın artmasına, dolayısıyla toprakta aşırı nem kaybına neden olur. Bu nedenle kurak bölgelerde, korumalı toprak işleme sistemlerinin geliştirilmesi ve uygulanmasının tarımsal sürdürülebilirlik ve üretkenliğin iyileştirilmesi için önemli bir firsat olduğu düşünülebilir (Godwin 1990). 


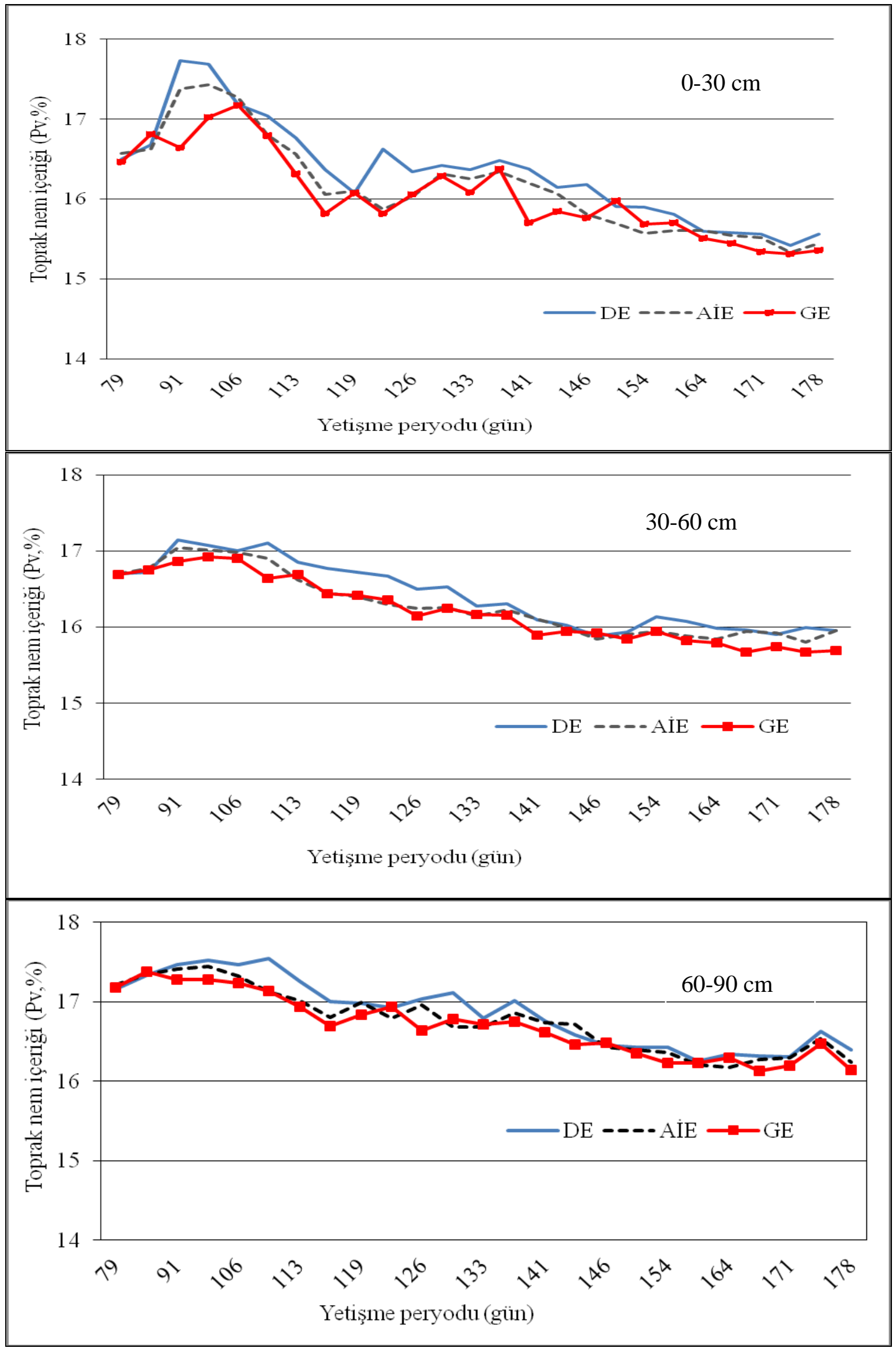

Şekil 4. Buğdayın yetişme periyodu boyunca toprak nem içeriğinin değişimi 
Bitki Su Tüketimi (ET)

Sulamasız koşullarda bitki su tüketimi değerleri Çizelge 5'de verilmiştir. Sulamasız koşullarda bitkinin tükettiği su miktarı istatistiki açıdan önemsiz bulunmasına rağmen tekniklere göre farklı1ık göstermiştir. Bitki su tüketimi (ET) değeri en yüksek GE tekniğinde bulunurken en düşük $\mathrm{DE}$ tekniğinde bulunmuştur.

Çizelge 5. Sulamasız koşullarda bitki su tüketimi değerleri

\begin{tabular}{|c|c|c|c|c|}
\hline Konular & Toplam Yağış (mm) & Etkil Yağış (mm) & $\Delta \mathrm{S}(\mathrm{mm})$ & $\mathrm{ET}(\mathrm{mm})^{*}$ \\
\hline $\mathrm{DE}$ & 305.1 & 268.8 & 45.8 & 314.6 \\
\hline AİE & 305.1 & 268.8 & 53.6 & 322.4 \\
\hline GE & 305.1 & 268.8 & 57.2 & 326.0 \\
\hline
\end{tabular}

*Sulamasız (kuru) Koşullarda, $\Delta \mathrm{S}$ : Tohum ekiminde ve hasatta ölçülen topraktaki nem farkı

Çalıșmada deneme alanına konumlandırılmıș iklim istasyonundan elde edilen parametreler kullanılarak FAO tarafindan geliştirilen CROPWAT (8.0) paket programı yardımıyla Penman-Monteith yöntemine göre ETo değerleri hesaplanmıștır (Çizelge 6). Sulama suyu miktarının belirlenmesinde kullanılan etkili yağış değerleri Çizelge 7'de verilmiștir. Buğday bitkisi Haziran ayı içerisinde hasat edildiği için ve bu ayda sulama gerekli olmadığından yetişme sezonu boyunca en yüksek günlük referans bitki su tüketimi $\left(\mathrm{ET}_{\mathrm{o}}\right)$ değeri $4.15 \mathrm{~mm} /$ gün olarak Mayıs ayında gerçekleșmiștir.

Çizelge 6. ETo değerleri ve hesaplama parametreleri

\begin{tabular}{|l|c|c|c|c|c|c|c|}
\hline Aylar* & $\begin{array}{c}\text { Min. } \\
\text { Sicaklık } \\
\left({ }^{\circ} \mathrm{C}\right)\end{array}$ & $\begin{array}{c}\text { Max. } \\
\text { Sicaklık } \\
\left({ }^{\circ} \mathrm{C}\right)\end{array}$ & $\begin{array}{c}\text { Oransal } \\
\text { Nem }(\%)\end{array}$ & $\begin{array}{c}\text { Rüzgar } \\
\text { Hızı }(\mathrm{m} / \mathrm{s})\end{array}$ & $\begin{array}{c}\text { Güneşlenme } \\
\text { Süresi (saat) }\end{array}$ & $\begin{array}{c}\text { Güneş } \\
\text { Radyasyonu } \\
\left(\mathrm{mj}^{2} \mathrm{~m}^{2} / \text { gün }\right)\end{array}$ & $\begin{array}{c}\text { ETo } \\
(\mathrm{mm} / \mathrm{gün})\end{array}$ \\
\hline Ocak & 4.5 & 12.8 & 74 & 0.9 & 3.8 & 2.5 & 0.38 \\
\hline Şubat & 4.0 & 15.8 & 54 & 0.5 & 6.0 & 5.7 & 0.43 \\
\hline Mart & 8.5 & 18.7 & 56 & 1.2 & 6.2 & 9.5 & 1.55 \\
\hline Nisan & 12.0 & 24.0 & 59 & 0.8 & 6.6 & 13.9 & 2.44 \\
\hline Mayıs & 15.3 & 28.0 & 50 & 1.4 & 8.0 & 18.4 & 4.15 \\
\hline Haziran & 19.6 & 32.6 & 52 & 1.2 & 10.3 & 22.3 & 5.10 \\
\hline Temmuz & 23.0 & 35.9 & 51 & 2.6 & 10.4 & 21.7 & 6.55 \\
\hline Ağustos & 23.1 & 37.4 & 52 & 2.2 & 9.4 & 17.9 & 5.67 \\
\hline Eylül & 18.4 & 31.5 & 50 & 1.7 & 8.2 & 12.6 & 3.63 \\
\hline Ekim & 11.2 & 24.9 & 54 & 1.2 & 6.6 & 7.1 & 1.54 \\
\hline Kasım & 9.8 & 19.7 & 64 & 0.6 & 4.0 & 3.0 & 0.45 \\
\hline Aralık & 1.6 & 10.5 & 71 & 1.0 & 3.5 & 1.8 & 0.42 \\
\hline Ortalama & 12.6 & 24.3 & 57 & 1.3 & 6.9 & 11.40 & 2.69 \\
\hline
\end{tabular}

*Temmuz-Aralık aylarına ait değerler 2013, Ocak-Haziran aylarına ait değerler 2014 yıllarına aittir.

Çizelge 7. Çalışma alanına ait yağış ve etkili yağış değerleri

\begin{tabular}{|l|c|c|}
\hline \multicolumn{1}{|c|}{ Aylar* } & Yağış $(\mathrm{mm})$ & Etkili Yağış $(\mathrm{mm})$ \\
\hline Ocak & 76.5 & 67.1 \\
\hline Şubat & 27.0 & 25.8 \\
\hline Mart & 112.4 & 92.2 \\
\hline Nisan & 30.2 & 28.7 \\
\hline Mayıs & 10.3 & 10.1 \\
\hline Haziran & 6.0 & 5.9 \\
\hline Temmuz & 0.0 & 0.0 \\
\hline Ağustos & 0.0 & 0.0 \\
\hline Eylül & 37.5 & 35.3 \\
\hline Ekim & 35.1 & 33.1 \\
\hline Kasım & 28.7 & 27.4 \\
\hline Aralık & 48.7 & 44.9 \\
\hline Toplam yağı̧̧ & 412.4 & 370.6 \\
\hline
\end{tabular}

*Temmuz-Aralık aylarına ait yıllık değerler 2013, Ocak-

Haziran aylarına ait yıllık değerler 2014 yıllarına aittir.
Çizelge 8'de ise sulanan koşullarda kışlık buğday için sulama zamanı planlaması verilmiştir. Sulama zamanı planlamasına göre kışlık buğday bitkisinin toplam net sulama suyu ihtiyaci 232.4 mm'dir. Bitki tarafindan kullanılan gerçek ET ise 501.2 mm'dir. Sulamasız koşullar dikkate alındığında bitkinin yetişme sezonu boyunca 501.2-321.0=180.2 mm nem açı̆̆ söz konusu olmuştur. Topraktaki nem düzeyi, bitki için daha çok kritik nem düzeylerinde kalmıştır.

Ergül (2011) yaptı̆̆ tüketimi değerini $334 \mathrm{~mm}$ ile nadas-buğday ekim nöbetinde, daha sonra $320 \mathrm{~mm}$ ile mercimek-buğday ve $310 \mathrm{~mm}$ ile buğday-buğday ekim nöbetinde bulmuştur. Yapılan bu çalışmada da buğdayın su tüketimi sulamasız koşullarda benzer sonuçlar vermiştir. 
Çizelge 8 . Kışlık buğday için sulama zamanı planlaması

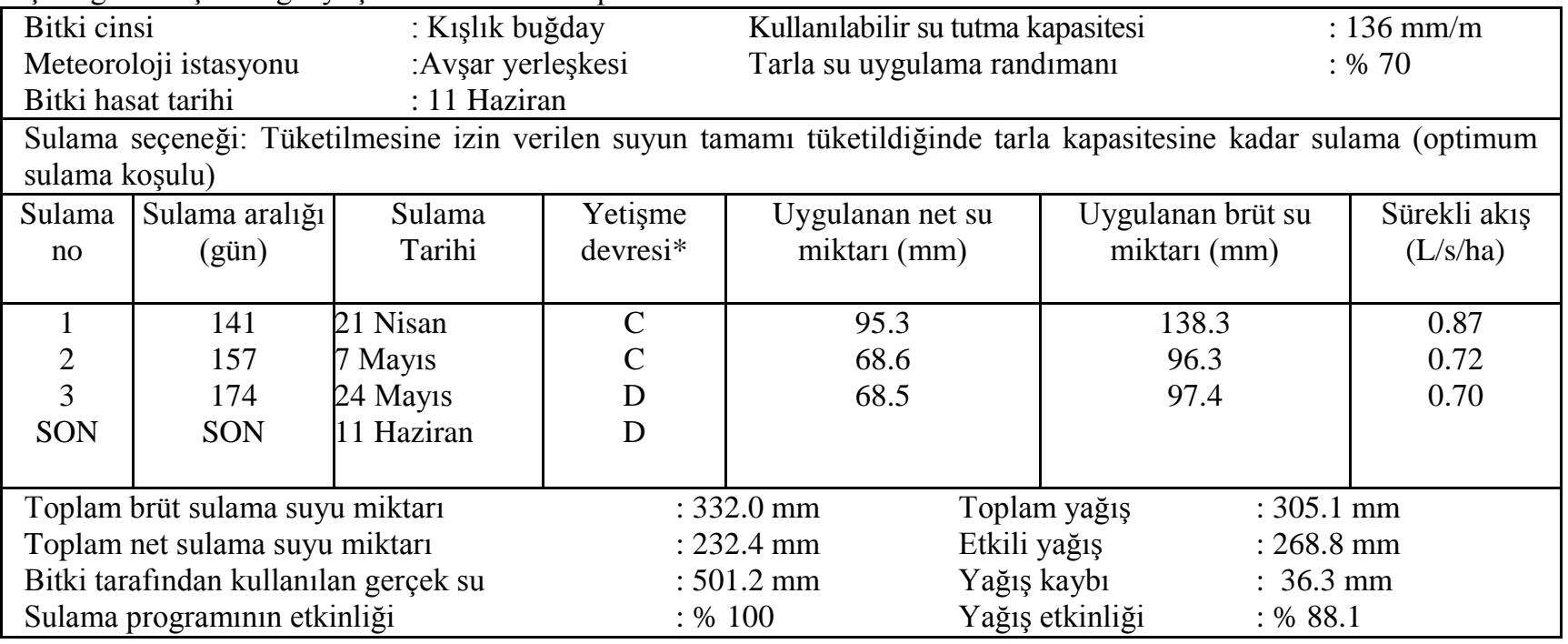

*A:Başlangıç devresi. B: Gelişme devresi. C: Olgunlaşma devresi. D: Hasat devresi

\section{Su Kullanım Randımanı (WUE)}

Farklı toprak işleme tekniklerinin WUE (\%) üzerine etkisi Çizelge 4,6'da verilmiştir. Ekim teknikleri arasındaki farklılık istatistiki olarak önemsiz çıkmıştır. Buna rağmen çizelgede görüldüğü gibi en yüksek WUE değeri doğrudan ekim tekniğinde (10.67) elde edilirken bunu sırasıyla az işlenmiş ekim tekniği (9.63) ve geleneksel ekim tekniği (9.46) izlemiştir.

Çizelge 9. Toprak işleme tekniklerine göre WUE değerleri

\begin{tabular}{|c|c|c|c|}
\hline Konular & $\begin{array}{c}\text { Tane Verimi } \\
(\mathrm{t} / \mathrm{ha})\end{array}$ & $\begin{array}{c}\text { Bitki Su Tüketimi } \\
(\mathrm{ET}, \mathrm{mm})\end{array}$ & $\begin{array}{c}\text { WUE } \\
(\mathrm{t} / \mathrm{ha} \mathrm{mm})\end{array}$ \\
\hline DE & 3358 & 314.6 & 10.67 \\
\hline AİE & 3107 & 322.4 & 9.63 \\
\hline GE & 3085 & 326.0 & 9.46 \\
\hline
\end{tabular}

Ergül (2011), iki yıl boyunca toprak işlemesiz ve toprak işlemeli konularda yaptığı çalışmada su kullanım etkinliği açısından birinci yıl ana parseldeki toprak işleme konuları arasındaki farklılık \%5 seviyesinde önemli çıkarken ikinci yıl önemsiz çıkmıştır. Toprak işlemesiz konuda su kullanım etkinliği birinci ve ikinci yıl sırasıyla 3.61 ve $3.99 \mathrm{~kg} / \mathrm{ha} \mathrm{mm}$, toprak işlemeli konu ise birinci ve ikinci y1l sirasıyla 7.21 ve $6.93 \mathrm{~kg} / \mathrm{ha}$ mm olarak bulunmuştur.

Jin ve ark. (2009) buğday-mısır ekim nöbetinde korumalı toprak işleme yöntemi ile buğdayda \% 30.1 ve mısırda \% 6.8 oranında su kullanım etkinliğinin arttığını belirlemişlerdir. Qingjie ve ark., (2009), kontrollü tarla trafiği konularında (sıfır toprak işlemeli ve sığ toprak işlemeli) su kullanım etkinliğinin, izledikleri 6 yılın 4 'ünde geleneksel toprak işleme uygulamasından daha fazla olduğunu bulmuşlardır.

So ve ark. (2009) soya bitkisinde su kullanım etkinliğinin sıfır toprak işlemede geleneksel toprak işlemeye göre arttığını belirlemişlerdir. Wagger ve Cassel (1993) su kullanım etkinliğinin silajlık mısırda sıfır toprak işleme ile arttığı, tane mısırda ise farklı toprak işleme sistemlerinde değişmediğini gözlemlemişlerdir. Benzer şekilde yapılan bu çalışmada da WUE değerinin DE tekniğinde GE tekniğine göre \% 13 arttığı belirlenmiştir.

\section{Bitkisel Parametreler}

Kuru koşullarda yetiştirilen buğday denemesinde elde edilen bitkisel parametrelere ait değerlere ilişkin varyans analizi ve Duncan testi sonuçları Çizelge 10'da verilmiştir. Çizelgede görüldüğü gibi sadece başak boyu istatistiki olarak önemli çıkmıştır. Ölçülen diğer parametreler; bitki boyu, başakçık sayısı, başaktaki tane sayısı, bin tane ağırlığı, tane verimi, sap verimi, toplam verim, hasat indeksi ve tane nemi ise önemsiz çıkmıştır. Fakat konular arasında DE tekniğinde elde edilen değerler diğer tekniklere göre büyük çıkmıştır.

Farklı toprak işleme tekniklerinin uygulandığı buğday denemesinde bitkinin yetişme periyodu boyunca bitki boylarının gelişme durumunu incelemek için ekimin 110. gününden itibaren bir hafta arayla ölçümler yapılmıştır. Çalışmada elde edilen buğday bitki boylarının zamana göre değişimi Şekil $5^{\prime}$ te gösterilmiştir.

Denemede bitki boyları ekimden 144. güne kadar hızlı bir artış gösterirken daha sonraki günlerde artış hızı azalmıştır. Burada ekimden 144. güne kadar yağan yağışların etkisiyle bitki boylarında hızlı bir artış olduğu daha sonra yağışların kesilmesi dolayısıyla topraktaki nem eksikliğine bağlı olarak bitki boylarındaki artış hızının azaldığı gözlemlenmiştir. Hasatta bitki boyu yaklaşık 60-65 cm dolaylarında sabit kalmıştır. Ekim tekniklerine bakıldığında konular arasında istatistiki olarak \%5 seviyesinde önemli çıkmıştır. $64.3 \mathrm{~cm}$ ile en yüksek değeri doğrudan ekim tekniği vermiştir. Bunu $63.1 \mathrm{~cm}$ ile az işlenmiş ekim tekniğ ve $60.6 \mathrm{~cm}$ ile 
geleneksel ekim tekniği izlemiștir. Burada doğrudan ekim tekniğinde toprak yüzeyindeki buğday anızının yağıșların etkinliğini artırarak bitki boylarının fazla olmasına neden olduğu söylenebilir.

Cizelge 10. Toprak işleme tekniklerinin bitkisel parametrelerindeki varyans analizi ve Duncan testi sonuçları

\begin{tabular}{|c|c|c|c|c|c|c|c|c|c|c|}
\hline Konular & $\begin{array}{c}\text { Bitki } \\
\text { Boyu } \\
(\mathrm{cm})\end{array}$ & $\begin{array}{c}\text { Başak } \\
\text { boyu } \\
(\mathrm{cm})\end{array}$ & $\begin{array}{c}\text { Başakçı } \\
\text { Sayı1 } \\
(\mathrm{adet})\end{array}$ & $\begin{array}{c}\text { Başaktaki } \\
\text { Tane } \\
\text { Sayı1 } \\
(\mathrm{adet})\end{array}$ & $\begin{array}{c}\text { Bin } \\
\text { Tane } \\
\text { Ağırlı̆1 } \\
(\mathrm{g})\end{array}$ & $\begin{array}{c}\text { Tane } \\
\text { Verimi } \\
(\mathrm{kg} / \mathrm{da})\end{array}$ & $\begin{array}{c}\text { Sap } \\
\text { Verimi } \\
(\mathrm{kg} / \mathrm{da})\end{array}$ & $\begin{array}{c}\text { Toplam } \\
\text { Verim } \\
(\mathrm{kg} / \mathrm{da})\end{array}$ & $\begin{array}{c}\text { Hasat } \\
\text { İndeksi } \\
(\%)\end{array}$ & $\begin{array}{c}\text { Tane } \\
\text { Nemi } \\
(\%)\end{array}$ \\
\hline $\mathrm{GE}$ & 64.30 & $7.94 \mathrm{a}$ & 16.27 & 38.90 & 35.48 & 335.83 & 535.20 & 871.00 & 39.20 & 13.29 \\
\hline $\mathrm{DE}$ & 63.13 & $7.81 \mathrm{a}$ & 16.00 & 38.70 & 35.21 & 310.66 & 514.73 & 825.39 & 38.01 & 13.23 \\
\hline AİE & 60.60 & $7.36 \mathrm{~b}$ & 15.43 & 38.37 & 35.13 & 308.55 & 480.57 & 806.54 & 39.10 & 13.23 \\
\hline $\begin{array}{c}\text { Önemlilik } \\
\text { Derecesi }\end{array}$ & ö.d. & $\mathrm{P}<0.05$ & ö.d. & ö.d. & ö.d. & ö.d. & ö.d. & ö.d. & ö.d. & ö.d. \\
\hline
\end{tabular}

ö.d.: önemli değil

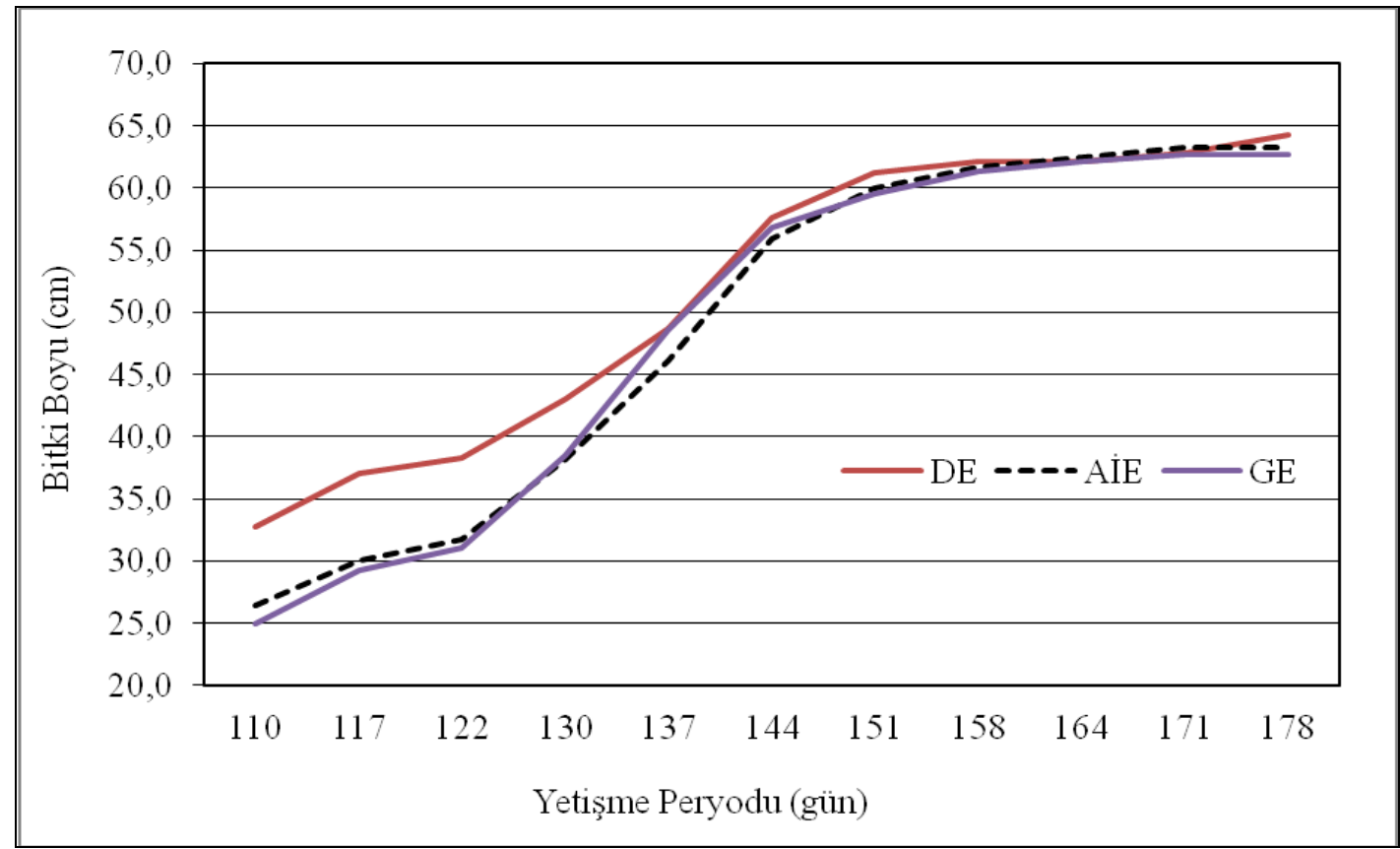

Şekil 5. Bitki boyunun zamana göre değişimi

Koç (2004)'de yapmış olduğu bir çalışmada, Çukurova koşullarında yetiştirilen Adana-99 buğday çeşidinde, bitki boylarının ekimden 164 gün sonraya dek susuz ve sulanan konuda hızla arttığını, daha sonra hasada dek sabit kaldığını belirlemiş olup, susuz konuda bitki boyunun $89.5 \mathrm{~cm}$; sulanan konuda ise, $96 \mathrm{~cm}$ 'ye dek ulaştığını belirlemiştir. Gill ve ark. (1990) ise, Hindistan, ABD, SSCB, Kanada, Macaristan, Avustralya ve Meksika'dan temin ettikleri 485 yazlık tritikale hattı ile yaptıkları bir çalışmada; tritikale hatlarında bitki boyunu $44.8-172.4 \mathrm{~cm}$ arasında değiștiğini bulmuşlardır. Yapılan bu çalıșmada elde edilen bitki boyu değerleri benzer sonuçlar vermiştir.

Turan (2008) yaptığı çalışmada Ceyhan-99'un bitki boyunu $97.6 \mathrm{~cm}$ olarak bulmuştur. Araştırıcı bitkinin vejetasyon dönemi boyunca $522.2 \mathrm{~mm}$ yağış meydana geldiğini belirtmiştir. Yapılan bu çalışmada bitkinin vejetasyon dönemi boyunca $211.1 \mathrm{~mm}$ yağış meydana gelmiştir. Kış aylarındaki yağışın mevsim normallerinden düşük olması buğdayda bitki boyunun azalmasına neden olmuştur.

\section{SONUÇ VE ÖNERILER}

Bu çalışma, doğrudan ekim, azaltılmış toprak işleme ve geleneksel toprak isleme tekniklerinin toprak nem içeriği ve ürün verimine etkisinin araştırılması amacı ile yapılmıştır. Toprak nem içeriği $0-30 \mathrm{~cm}$ toprak katmanında yetişme periyodunun ilk zamanlarında konu edilen ekim teknikleri arasında farklılık gösterirken hasada doğru bu fark azalmış ve sırasıyla DE'de \%15.6, AİE'de 15.4 ve GE'de 15.3 olarak bulunmuştur. Toprak katmanının $30-60$ ve $60-90 \mathrm{~cm}$ 'sinde ise nem düzeyleri büyükten küçüğe doğru DE, AİE ve GE teknikleri şeklinde bir sıralama göstermiştir. Toprak katmanın 30- 
60 cm'sinde DE'de \%15.9, AİE'de 15.9 ve GE'de 15.6 iken $60-90$ cm'sinde ise DE'de \%16.4, AİE'de 16.2 ve GE'de 16.1 olarak bulunmuştur. Hasatta nem değerleri $30-60$ ve $60-90 \mathrm{~cm}$ katmanında 0-30 cm katmanına göre daha yüksek çıkmıştır. Her üç katmanda vejetasyon devresi boyunca topraktaki nem seviyesi 0-30, 30-60 ve 60-90 katmanlarda sirasiyla kullanılabilir nemin $\% 50$ 'sinin tüketildiği kritik nem seviyeleri olan \%20.1, $\% 20.7$ ve $\% 18.8$ olan nem düzeylerinin altında kalmıştır.

Sulamasız kuru koşullarda bitkinin tükettiği su miktarı 188.3-199.7 mm arasında değişmiştir. Çalışma alanına yerleştirilen iklim istasyonu, toprak ve bitki verileri kullanılarak CROPWAT 8.0 bilgisayar paket programı ile kışlık buğday için yapılan sulama zamanı planlamasına göre bitki tarafından kullanılan gerçek su 304.2 mm bulunmuştur. Dolayısıyla kurak koşullarda yetiştirilen kışlık buğday bitkisinde 304.2-194.7=109.5 mm nem açığı söz konusu olmuştur. Vejetasyon süresi boyunca topraktaki nem düzeyi, bitki için daha çok kritik nem düzeyinin altında kalmıştır. Bu durum bitki veriminde düşüşlere neden olmuştur.

İncelenen bitkisel parametrelerden başak boyu \% 5 olasılık düzeyin de istatistiksel olarak önemli olarak bulunmuşlardır. En uzun başak boyu $7.9 \mathrm{~cm}$ ile DE tekniğinde elde edilmiş olup, bunu $7.8 \mathrm{~cm}$ ile AİE yöntemi izlemiştir. En kısa başak boyu ise, GE metodunda 7,4 cm olarak ölçülmüştür.

Bitki boyları açısından ekim teknikleri arasında istatistiksel olarak fark tespit edilmezken, $64.3 \mathrm{~cm}$ ile en fazla bitki boyu DE tekniğinde elde edilirken, bunu sirasıyla $63.1 \mathrm{~cm}$ ile AİE ve $60.6 \mathrm{~cm}$ ile GE teknikleri izlemiştir. Bin tane ağırlığı, başaktaki başakçık sayısı, başaktaki tane sayısı, toplam verim, sap verimi, hasat indeksi ve tane nemi bakımından varyasyon analizinde toprak işleme teknikleri arasında istatistiksel olarak önemli farklılıklar olmamıştır. Buna rağmen en yüksek sonuçlar DE tekniğinde görülmüştür.

Kahramanmaraş ilinde küresel 1sınmadan kaynaklanan iklim değişiminin, en çok tarım sektörünü etkileyeceği yadsınamaz bir gerçektir. Sıcaklık artışı ve yağış azalmasının öngörüldüğü Kahramanmaraş ilinde tarımsal verimliliğin doğrudan etkileneceği düşünüldüğünde, iklim değişikliğinin toprak nemi üzerindeki etkilerini inceleyen farklı toprak işleme tekniklerinin sonuçları, gerek bölgesel ekonomiye ve gerekse kırsal kesimdeki sosyal refaha etkilerinin büyük olacağ1 düşünülmektedir. Kı değiştiremeyeceğimiz ve dünyanın büyük bir bölümünü etkileyecek olan olası iklim değişiminin sonuçları ile başa çıkabilmemiz, ancak onu, izleyebilmemiz ve eğer varsa alınabilecek önlemleri alabilmemize bağlı olacaktır. Bitki gelişim periyodunda bitki için gerekli nemin toprakta yeterli miktarda bulunması verim açısından çok önemlidir. Küresel 1sınmadan kaynaklanan aşırı sıcaklıktan kaynaklan toprak nemi kayıplarını azaltabilmek için Kahramanmaraş ili gibi yarı kurak ve kurak iklim bölgelerinde DE tekniğinin kullanımına önem verilmelidir.

\section{KAYNAKLAR}

Akkaya, A., Akten, Ş. 1988. Susuz Koşullarda Yetiştirilen Bazı Kışlık Buğdayların Toplam Verimi, Dane Verimi Ve Hasat İndeksi Üzerine Bir Araştırma. Atatürk Üniv. Zir. Fak. Der., 19 (1-4): 133-144.

Anonim. 2014. Kahramanmaraş Meteorloji İl Müdürlüğü Envanter Kayıtları, Kahramanmaraş.

Anonim, 2015. www.dsi.gov.tr/docs/sunumlar/ustgnmd-sunumu.pptx?sfvrsn=2 (Erişim: Eylül 2015).

Beyribey, M., 1992. GAP Sulama Projelerinde Sulama Suyu İhtiyacı ve Sistem Kapasitesi Üzerine Bir Araştırma, A.Ü. Ziraat Fakültesi, Yayın No:1245, S.25-28, Ankara.

Biber, Ç., Kara T., 2006. Misır Bitkisinin Bitki Su Tüketimi Ve Kısıtlı Sulama Uygulamaları. J. of Fac. of Agric., OMU, 21(1), 140-146.

Brady, N. C., Weil, R. R. 1996. The nature and properties of soils. (No. Ed. 11). Prentice-Hall Inc., New York, USA

Dinçer, M.N. 1991. Çukurova Bölgesinde Bitki Büyüme Düzenleyicisi Kullanılarak Yetiştirilen Bazı Ekmeklik ve Makarnalık Buğday Çeşitlerinde Farklı Azot Dozlarının Verim ve Verim Unsurlarına Etkisi Üzerinde Araştırmalar. Ç. Ü. Fen Bilimleri Enstitüsü, Tarla Bitkileri Anabilim Dalı, Doktora Tezi, Adana.

Ergül, F. 2011. Farklı Toprak İşleme ve Ekim Nöbeti Sistemleri Altında Su Bütçesi, Bazı Toprak Fiziksel Özellikleri ve Buğday Verimindeki Değişimlerin Saptanması, A. Ü. Fen Bilimleri Enstitüsü, Toprak Bilimi ve Bitki Besleme Anabilim Dalı, Doktora Tezi, Ankara, 82s.

Godwin, R.J. 1990.Agricultural Engineering in Development Tillage for Crop Production in Areas of Low Rainfall. Food and Agriculture Organitation of the United Nations, Roma.

Hoogmoed, W., Rawitz, E. 1979. Soil Tillage in Dry Tropical Regions. Proceedings of The International Soil Tillage Research Organization, ISTRO $\left(8^{\text {th }}\right.$ Conferance), Volume, 1, 21-26. Lİndwall, C.W. and Anderson, D.T., (1981). Agronomic Evalat İon of Minimum Tillage Systems of Summer Fallow in Southern Alberta. Canadian J. Plant Sci., 61,(2), 247-253

Howell, T.A., Cuenca, H.A., Solomon, K.H. 1990. Crop Yield Response Management of Farm Irrigation Systems. Trans. ASAE Monograph Chap S. USA

İlbeyi, A. 2001. Türkiye'de Bitki Su Tüketimleri Tahmininde Kullanılacak Bitki Katsayılarının Belirlenmesi, AÜ Fen Bilimleri Enstitüsü, Doktora Tezi, Ankara, 179 s.

İşler N., 2012. Farklı Toprak Düzenleyicilerin Toprak Nemi Üzerine Etkileri ve HYDRUS 2D ile Modellenmesi. (Yüksek Lisans Tezi). Çanakkale Onsekiz Mart Üniversitesi, Çanakkale.

James, L.G. 1988. Principles of Farm Irrigation System Design. John Wiley and Sons. Inc, New York. 543s. 
Jin, H., Qingjie, W., Hongwen, L., Lijin, L., Huanwen, G. 2009. Effect of Alternative Tillage and Residue Cover on Yield and Water Use Efficiency in Annual Double Cropping System in North China Plain. Soil and Tillage Research, 104(1); 198-205.

Kırtok, Y. 1982. Çukuova'nın Taban ve Kıraç Koşullarında Ekim Zamanı, Azot Miktarı ve Ekim Sıklığının ki Arpa Çeşidinde Verim ve Verim Unsurlarına Etkileri Üzerine Araştırmalar. ÇÜ Ziraat Fakültesi Yıllığı, Ayrı Baskı, Y1l 13, Sayı:3-4.

Koç, D.L. 2004. Çukurova Koşullarında Bowen Oranı Enerji Dengesi Yöntemiyle Buğday Su Tüketiminin Belirlenmesi. Çukurova Üniversitesi, Fen Bilimleri Enstitüsü, Tarımsal Yapılar ve Sulama Anabilim Dalı, Yüksek Lisans Tezi. 34-40, Adana.

Smith, M. 1991. Introduction to Irrigation System Performance: Comparative Analysis of Case Studies. Improved Irrigation System Performance for Sustainable Agriculture. Proceedings of the Regional Workshop Organised by FAO in Bangkok, Thailand. 22-26 October 1990, p. 25-35, Rome.
So, H.B., Grabski, A., Desborough, P. 2009. The Impact of 14 Years of Conventional and No-Till Cultivation on the Physical Properties and Crop Yields of a Loam Silt at Grafton NSW, Australia. Soil and Tillage Research, 104(1); 180-184.

Turan, I. 2008. Kahramanmaraş Koşullarında Bazı Buğday, Arpa Ve Tritikale Çeşitlerinin Verim Ve Verim Özelliklerinin Belirlenmesi, KSÜ. Fen Bilimleri Enstitüsü, Tarla Bitkileri Anabilim Dalı, Yüksek Lisans Tezi, Kahramanmaraş, 42s.

Uluöz, M. 1965. Buğday, Un Ve Ekmek Analiz Metodları. E.Ü.Ziraat Fakültesi. Yayınları No: 57. E.Ü. Matbaas1, Bornova.

Ünlükalayc1, A. 1994. Konya Ilgın Atlantı Ovası Sulamasında Su Dağıtım ve Kullanım Etkinliği. A. Ü. Fen Bilimleri Enstitüsü Tarımsal Yapılar ve Sulama Anabilim Dalı, Doktora Tezi, Ankara.

Wagger, M.G., Cassel, D.K. 1993. Corn yield and water-use efficiency as affected by tillage and irrigation. Soil Sci. Soc. Am. J., 57; 229-234. 